\title{
Analysis of Interest Deduction Rules Under Ethiopian Corporate Tax System
}

\author{
Desalegn Deresso Disassa \\ School of Law, Assosa University, Assosa, Ethiopia
}

\section{Email address:}

sifdese99@gmail.com

\section{To cite this article:}

Desalegn Deresso Disassa. Analysis of Interest Deduction Rules Under Ethiopian Corporate Tax System. International Journal of Science, Technology and Society. Vol. 8, No. 6, 2020, pp. 122-137. doi: 10.11648/j.ijsts.20200806.11

Received: August 31, 2020; Accepted: September 19, 2020; Published: November 23, 2020

\begin{abstract}
The use of third party and related party interest is one of the profit-shifting techniques available in international tax planning. The fluidity and fungibility of money make it a relatively simple exercise to adjust the mix of debt and equity in a controlled company. When the level of debt capital is much greater than the equity capital of the company thin capitalization occurs. Nowadays, thin capitalization is one of the major challenges to the corporate tax system of Ethiopia. Thin capitalization reduces government income from tax by increasing deductible interest paid or payable on the debt. To address this problem, Ethiopia has implemented tax rules restricting the deductibility of interest payments. This article aims to qualitatively examine the interest deduction rules under the Ethiopian income tax regimes through a qualitative analysis of existing literatures and laws. To this end, the analysis start unfolding the conceptual framework of interest deduction and its rules followed by an examination of interest deduction rules of Ethiopia. As the finding has revealed, the newly enacted federal income law has taken a big step in tightening the interest deduction rules through the adoption of debt-to-equity ratio and arm's length approach to determine the maximum debt on which interest deductible. In doing so, the income tax rules of Ethiopia incorporated the indirect interest deduction rule which indirectly limits the amount interest on which is deduction is allowable. In addition to this, the withholding tax imposed on interest paid to non-resident and limit on maximum deductible interest rates are adopted as an interest deduction approach to supplement arm's length and debt-to-equity ratio to protect tax base erosion. Despite these positive developments, the Ethiopian tax law has failed to recognize direct interest deduction rules which directly limit the maximum interest on which deduction is allowed. Nowadays, interest stripping rule is widely appreciated as the modern and most effective approach that directly restricts interest deduction. So, the failure to introduce a direct interest deduction rule is one of the major defect interest deduction rules in Ethiopia. Besides, the income tax law has failed to limit the special debt-equity ratio that applies to financial institutions. Furthermore, the tax law has failed to set a maximum deductible rate that applies to financial institutions licensed to lend in Ethiopia. To fill these gaps and ensure efficient protection of the tax base against erosion by deduction of interest payment, the researcher called for a direct interest deduction rule. Besides, the researcher called for the introduction of the debt-equity ratio that applies to a financial institution and the maximum deductible interest rate concerning the interest payment to legitimate financial institutions.
\end{abstract}

Keywords: Thin Capitalization, Thin Capitalization Rules, Interest Deduction, Income Tax

\section{Introduction}

A company is usually financed through income from its business activities, equity (owner contribution), and debt (loan from creditors) [1]. The share of debt and equity in the company's finances may vary. Thin capitalization arises when a company is financed through a relatively high level of debt compared to equity. Such a company is called a thinly capitalized company. For many decades, the proper tax treatment of interest payments has challenged tax authorities. The issues include how excessive interest is determined. Generally, interest on the debt is deductible, while the dividend on equity is non-deductible. As a result, from a tax angle, it is attractive or provides an incentive for companies to base on debt finance rather than equity especially in a high tax jurisdiction. The extensive increment of debt financing of companies reduce tax revenue and affect the country's economic competitiveness. Besides, interest deduction causes 
increases in the cost of equity, affect corporate finance decision making, raises resource misallocation, and causes unfair competition between multinational corporations and domestic companies, and increase tax planning costs of firms. To counteract such negative consequences, countries use thin capitalization rules or interest deduction rules that differ in dimensions and approaches. Interest deduction rules try to control tax planning of thinly capitalized companies by setting a limit on maximum debt or interest on which deduction is allowed. In order to limit interest deduction, Ethiopia has introduced thin capitalization rules (aka interest deduction rules) under its income tax laws. Against this backdrop, this article tries to examine the legal (not economic) aspect of the interest deduction rules under the Ethiopian income tax regime. In this context, the article address issues concerning the interest deduction and the ways the income tax regime of Ethiopia addressed it.

To this end, the article start unfolding the meaning and rationale of thin capitalization, raison d'être of thin capitalization rules, and the legislative approaches that countries frequently adopt to thin capitalization rules. Finally, it is not the aims of this article to provide empirical evidence on the effectiveness of thin capitalization rules and its effect on resource allocation, competition between multinational corporations and domestic companies', cost of tax planning, cost of equity and debt, financing, and investment decisions.

In this article's analysis, the researcher has utilized qualitative methodology in which an attempt to analyze the state of thin capitalization rules or interest deduction rules under the income tax regime of Ethiopia is done through examinations of relevant laws, policies, and literatures. The study used doctrinal research methodology in the sense that the review is a desk-based analysis of relevant laws and literatures on interest deduction. In this context, the analysis of the interest deduction rules under the income tax regime is done. The study utilized both primary and secondary sources of data including laws, policies, strategies books, articles, reports, journals, legal periodicals, thesis, and dissertation. To get firsthand data analysis of law and polices were done. A qualitative data analysis method is utilized to analyze and interpret the collected data. By its nature qualitative data analysis is an on-going process, taking place throughout the data collection process. Thus, the researcher has analyzed the data as the study progresses, continually refining and reorganizing in light of the emerging results. Within the qualitative approach, the researcher used an explanatory or analytical approach to critically analyze and explain data collected concerning thin capitalization rules and regulations under the Ethiopian income tax regime.

\section{Conceptual Frameworks}

\subsection{Debt and Equity}

Thin capitalization occurs when the degree of debt is greater than equity within the capital of the company. This triggers the issue of what is debt and equity. The meaning of debt and equity in the normal course of the business is different from its meaning for tax purposes. Debt refers to anything including loan and bond which entitles the holder to receive a fixed, periodic return, typically called interest. The holder of debt lacks an ownership interest. On the other hand, equity represents an ownership interest of the holder in the underlying entity. Here the term "equity" is not limited to its classically understanding as share or stock. Both equity and debt are the sources of finance during the formation and operation of the company.

A debt that results in payment of interest may be incurred as part of the capitalization of the enterprise in combination with equity during the formation of the company. Debt may also be incurred in connection with the purchase of property or goods which result in payment of interest because of the late payment of the price. In the daily operation of the company, debt may be incurred to support the working capital required to pay salaries, suppliers, and other expenses in the ordinary course of business. Normally, like equity, debt is one source of finance that ensures the effective operation of the company. The difference between the two sources of company finance is tax treatment. As a matter of principle, for the taxpayer, interest payments generally are viewed as an ordinary deductible business expense in determining taxable income. On the other hand, payments concerning equity are normally non-deductible.

\subsection{Debt Financing and Thin Capitalization}

Thin capitalization occurs when the contribution of debt finance in the capital structure of the company is substantially greater than equity finance. This can raise the question of why a company chooses debt financing and get thin capitalized. A company uses debt and become thinly capitalized for non-tax and tax considerations [2]. Generally, the availability and use of debt is widely recognized as an important element of a healthy business environment. Indeed, a lack of credit can deter the growth of a business. In other words, the availability of debt is often essential to economic growth. Debt financing is not a problem by itself and is not prohibited. As a result, the use of debt in financing the operation of the firm does not necessarily prove the existence of the intent of the tax-avoidance plan. This show, while tax issues are often an important driver in deciding whether to use debt or not, there can be significant non-tax considerations as well. Rather than for tax avoidance, the taxpaying investor may use debt to finance its investment which in return ensures an increase in tax revenue.

The focus of this article is on is tax concerns of debt financing and thin capitalization. From a tax standpoint, generally, companies favor debt over equity finance. Debt financing reduces or even eliminates tax liability for companies. Thus, tax incentives or tax reliefs in the form of deduction of interest on the debt is the reason for debt financing and thin capitalization thereof. This makes debt financing more attractive to especially associated companies to shift profits from one country to another for tax avoidance. 
The company uses debt finance and get thinly capitalized to reduce its tax burden legally. Multinational corporations often structure their financing arrangements to maximize these benefits of tax minimization. To this end, multinational corporations fund overseas investments by a subsidiary in high-tax jurisdictions with a high debt-to-equity ratio to have interest deduction in high-income tax countries and shift the profit back to lower-income countries. The way income can be shifted from one jurisdiction to another is called "interest stripping" or "earning stripping" since the taxable income is stripped from one jurisdiction tax environment by interest deductions [3]. Thin capitalization is a financing strategy that multinational corporations use to make Foreign Direct Investment (FDI) benefit from tax relief or tax deduction on interest paid on debt. Multinational corporations use thin capitalization strategies to shift earnings from high-tax to low-tax jurisdictions in the form of intercompany debt. However, because of the deductibility of interest, thin capitalization has negative effects of reducing taxable income which in turn reduces tax revenue of the government [4].

\subsection{Justifying Interest Deduction Rules}

The capital structure of the company or how the company is financed has a significant impact on the amount of profit it reports for tax purposes. Equity financing increases the amount of taxable income. In contrast, debt financing decreases the amount of taxable income because of the deduction of interest paid on the debt. In other words, as interest paid on debt increase taxable income decrease and the reverse is true. This indicates as compared to equity, debt is a tax-efficient method of financing for the company to reduce its liability. Even if thin capitalization is tax-efficient for companies this logic is not true for the tax revenue of the government [5]. Tax laws usually allow a deduction for interest paid or payable in arriving at the tax measure of profit. The higher the level of debt in a company, and thus the amount of interest it pays, the lower will be its taxable profit. This will negatively affect the revenues of the government from tax. As a result, there a need to defend tax base or government revenue against interest deduction. The government defends its tax revenues against companies' tax planning strategies using interest deduction rules. Thin capitalization rules restrict the implementation of abusive financing structures which might lead to erosion of the tax base and the transfer of profits to another jurisdiction where the profits were taxed at a lower rate.

Interest deduction rules may indirectly limit the availability of finance for a company to undertake its business activities. In doing so, the rule may affect the investment of the company which in turn affects the overall profitability of the company and revenue of the government. To solve such a problem thin capitalization rules should make a distinction between debt financing for-tax and nontax reason. In this regard, the Organization of Economic Cooperation for Development (OECD) has the stand that raising debt for non-tax factors is acceptable and should not be restricted. However, the problem is that it is difficult to distinguish debt incurred for tax or non-tax factors. Of course, interest deduction rules do not prohibit debt finance but it limits the interest deduction for tax purposes [6]. In doing so, the rational of interest deduction rules is protecting the revenue of the government against tax avoidance activity of the company through debt financing without affecting the availability of finance for the company to finance its business activities. So, the protection of the tax base against erosion is one of the driving factors to impose legal limits on the deductibility of interest payment through interest deduction rules. The interest deduction rule is designed to disallow the deduction of the excessive interest payment concerning excessive debt. Furthermore, the limit on the deductibility of interest reduces the advantage of multinational corporations over purely domestic businesses that are unable to gain such tax advantages [7].

Taxpayers may argue against a limit on interest deduction claiming that the tax law should not limit interest deductions as long as the taxpayer is compliant with non-tax rules establishing the level of debt that is lawfully earned and any prudential limitations imposed [8]. In such a case, the interest expense incurred is a reasonable business cost and should be deductible in determining taxable income. Despite argument for and against limiting interest deduction, tax laws often set limits on deductible expenses for policy reasons. As the name implies, interest deduction rules impose a limit on the deductibility of interest when debt or interest thereof is determined to be excessive [9]. The approaches adopted in determining whether a company has excessive or nondeductible debt or interest is discussed in the sections below.

\subsection{Approaches to Interest Deduction Rules}

Thin capitalization indicates the condition in which a taxpayer is determined to have excessive debt and therefore excessive interest expense. In most cases, tax rules regarding thin capitalization focus on the debt owed and the interest paid to non-residents. Because, if the recipient of the interest is resident, the interest received is subject to tax as income of the recipient. As a result, debt owed and interest to a resident is not a big concern of interest deduction rule which tries to prevent tax base erosion and profit shifting.

Countries' interest deduction regimes may differ in different dimensions [10]. Countries adopt different approaches to thin capitalization rules. As the review of countries' experiences conducted by the OECD in 2017 reveals, interest deduction rules currently applied fall into six groups, with some countries using a combined approach that includes more than one. The six operational interest deduction approaches include (1) arm's length tests, which compare the level of interest or debt in an entity with the position that would have existed had the entity been dealing entirely with third parties; (2) withholding tax on interest payments, which are used to allocate taxing rights to a source jurisdiction; (3) rules which disallow a specified percentage of the interest expense of an entity, irrespective of the nature 
of the payment or to whom it is made; (4) rules which limit the level of interest expense or debt in an entity with reference to a fixed ratio, such as debt-equity, interestearnings or interest-total assets; (5) rules which limit the level of interest expense or debt in an entity with reference to the group's overall position; and (6) anti-avoidance rules which disallow interest expense on specific transactions[11].

As indicated above, the thin capitalization rules usually operate utilizing one of two approaches: determining a maximum amount of debt on which deductible interest payments are available, and determining a maximum amount of interest which is deductible by reference to the ratio of interest paid or payable to another variable. More precisely, usually thin capitalization rule is designed in a way that determines maximum debt or interest which deductible. For this reason, interest above the maximum debt or interest is not deductible. Besides, interest deduction rules operate imposing withholding tax on interest payment and fixing the maximum interest rate on which deduction is allowed.

From inception, thin capitalization rules generally evaluate the firm's balance sheet to determine if the companies' financing structure was excessively leveraged. This means the majority of thin capitalization rules established the existence of safe harbor (for instance, debt-to-equity ratios) to force related companies to apply normal market conditions in their intra-group transaction. Lund, Korsgaard, and Albertsen also agree, specific rules aimed to discourage thin capitalization often require that the debt-to-equity ratio meet a specific ratio for the company to be allowed to deduct interest expenses. However, currently, several countries have shifted their approach to combat these financing strategies. Because, there has been a tendency for some countries to base their rules on a company's operations, and more and more countries are introducing so-called interest limitation rules and earnings stripping rules [12].

Usually, thin capitalization rules and interest deduction rules can be used interchangeably to refer to something. Sometimes scholars treat them differently. Given that, thin capitalization rules limit a firm's debt-to-equity ratio to control highly leveraged financing structures, while interest deduction regulations directly limit the tax-deductible interest expense a firm can recognize. Some countries employ either thin capitalization rules or interest deduction limitations, but many countries use a combination of regulations to combat excessive financial leverage. In other words, an interest deduction limitation rule is classified as a direct and indirect limitation rule. The direct interest limitation rule (interest deduction rules) restricts the amount of interest an entity may deduct for tax purposes, whereas an indirect rule (thin capitalization rules) restricts the amount of debt concerning which an entity may claim interest deductions. For example, OECD elected the direct approach i.e. fixed ratio rules based on earnings before interest, tax, depreciation, and amortization (EBITDA). Despite the difference in scope and meaning, unless the contexts require otherwise, thin capitalization rule and interest deduction rule are used interchangeably in this article. Some approaches to thin capitalization are briefly discussed herein under.

\subsubsection{Limiting Excessive Debt}

In order to calculate taxable profit, thin capitalization rules often operate by limiting the amount of debt that can give rise to deductible interest expenses. Within the cap of debt, interest is tax-deductible. The interest payments on the debt above the limit or excessive debt are non-deductible for tax purposes [13]. Thin capitalization rules which limit the maximum amount of debt on which interest payment is deductible does not directly, but indirectly set the limit of the amount of interest on which deduction is allowed or disallowed. The two broad approaches adopted by countries to determine the maximum amount of debt that can give rise to deductible interest payments are the arm's length approach and ratio approach.

The Arm's Length Approach

As per this approach, the maximum amount of allowable debt is the amount of debt that an independent lender or an arm's length lender would be willing to lend to the company. That is the amount of debt that a borrower could borrow from an arm's length lender. This approach considers the specific attributes of the company in determining its borrowing capacity or the amount of debt that the company would be able to obtain from independent lenders. To this end, it requires the taxpayer company and tax authority to establish the amount of debt a third party lender would be willing to lend to it taking into account its specific attributes. The approach can also take into consideration the amount the lender, acting at arm's length, would be willing to borrow. Many approaches may be taken in using this approach.

The arm's length approach also encompasses a determination of the amount of debt that a borrower would have borrowed if the lender had been an independent company acting at arm's length. The "would-have approach" determines the amount of debt that would have been obtained under arm's length conditions. It considers whether the loan would have been entered into by the borrower if it had been dealing with the lender under arm's length conditions. The interest may be disallowed on debt that could have been obtained from an arm's length lender, but, at arm's length, would not have been obtained. To this end, tax authorities typically investigate the circumstances under which individual items of debt, or incremental or new debt, has been obtained. They will ask whether there is a business or commercial reason for this debt.

The arm's length approach has its advantage and disadvantage. The advantage of the arms-length approach is that it provides for a much closer approximation of the debt the company could borrow at arm's length and thus removes asymmetrical treatment between companies that are members of multinational corporations and those that are not. It is tailored to the facts and circumstances of each case and allows a more tailored approach to the determination of deductible debt interest. It may be achieved through a country's general transfer pricing rules. It may also allow the elimination of double taxation through the application of a 
tax treaty if it is accepted by both parties to the treaty that the approach represents the application of the arm's length principle and thus falls within the associated companies' article of the relevant treaty.

The use arm's length approach also has a disadvantage. Among these, utilizing it requires large resource and skill requirements. The tax auditor needs to understand the processes that third-party lenders use to determine the maximum amount they would lend to a specific taxpayer. Tax auditors shall have a significant understanding of third party lending practices and need to investigate the application of those criteria with regards to specific taxpayers, and, inevitably, this will require a degree of judgment to determine the proper treatment for each factual situation. Tax authorities need to have the expertise to step into the role of the third party lender and establish the specific characteristics of the group affiliate to determine an appropriate amount of debt. This may involve discussions with third party lenders to understand how a third party would determine how much it would be willing to lend.

\subsubsection{The Ratio Approach}

Under this approach, the maximum amount of debt on which interest may be deducted for tax purposes is established by a pre-determined ratio, such as the ratio of debt to equity. The debt-equity ratio of the company is the most frequently adopted approach to determine whether a company has a reasonable amount of debt. The debt-equity ratio is frequently expressed as a fixed ratio. Usually, the tax law set different debt-to-equity ratio for the company which operates as a financial institution and other industrial company. Compared to other firms, because of its business model, the financial institution has a high debt ratio. Because of this, the tax rule typically fixes a higher debt-to-equity ratio for a company that operates as a financial institution to render financial services. For instance, an industrial company may be required to have a debt-equity ratio no higher than $2: 1$, while a financial institution may be required to have a debt-equity ratio no higher than, say, 4:1. Determining the debt-equity ratio admittedly involve arbitrary element as there is no correct ratio for businesses. The ratios can be fixed by observing a broad range of businesses.

The ratio or ratios used may or may not be intended to reflect an arm's length position. Ratio approaches determine the amount of deductible interest expense by reference to a specified ratio, such as the ratio of debt to equity. Thus, interest payments on debt above the predetermined ratio of debt to a given variable that may be equity would not be deductible. Many countries have prescribed rules to deal with the debt-equity mix by placing a ceiling on the debt-equity ratio. Some rely on the transfer pricing rules to determine an acceptable debt-equity ratio. Countries set different debtequity ratio. In applying such ratios, countries may use only either related-party debt in the equation or total debt as the basis. Another type of ratio compares the debt to equity ratio (or other financial indicators) of the entity under consideration to the worldwide group debt (or other financial indicators) to worldwide equity to determine (for the thin capitalization rules) if the group affiliate's debt level is excessive. Countries adopt many approaches to applying ratio approaches. Some countries aim to determine ratios to approximate an arm's length position. Others determine ratios according to other criteria.

Where the ratio is determined according to the arm's length criteria, some countries treat the specified ratios as equivalent to a safe harbor. Under this approach, taxpayers will have some certainty that interest that falls within the specified parameters will be considered to be acceptable. Interest that is more than the safe harbor may be challenged, however, and potentially disallowed, unless the taxpayer can show that the excess interest represents an arm's length amount. Other countries apply the specified ratios more inflexibly.

Ratio rules which employ the concepts of debt and equity necessarily need to define these terms. For thin capitalization, debt is not limited to financial instruments classified as debt under accounting standards. Thus debt is any instrument that gives rise to an interest that is paid or payable that is otherwise deductible in the computation of taxable profit. However, the country may define debt as related-party debt only, whereas others apply total debt in the relevant ratios. Most countries define equity in a broad sense, including share capital, capital contributions, retained profits, interestfree loans, or revaluation reserves.

The ratio approach has its advantage and disadvantage. The advantage of a ratio approach is that it provides a great deal of certainty and reduces compliance costs to companies and taxing authorities. The rule is simple to implement and reduces the resource costs of tax authorities. The disadvantage of the fixed ratio approach is that it does not necessarily reflect economic reality and may distort behavior by group affiliates. A fixed ratio approach does not always take into account specific market situations or industries and may result in inconsistent treatment of members of multinational enterprises in comparison to independent companies. Thus, it is inflexible. Besides, there is no agreed international standard for the formulation of an appropriate ratio.

Like the arm's length approach, the debt-to-equity ratio approach also encompasses the "Would-have approach". The "would have" approach considers whether there is a commercial need or justification, from the borrower's perspective, for all or part of a company's debt. The tax authorities thus typically investigate the circumstances under which individual items of debt, or incremental or new debt, has been obtained. They will ask whether there is a business or commercial reason for this debt; or, as a corollary, whether there is a tax motive for entering into new debt. This requires a detailed investigation.

\subsection{Limiting Excessive Interest- Interest Stripping Rules}

The second approach adopted by countries in designing their interest deduction rule is an interest stripping rules. 
Under this approach, a maximum amount of interest that may be deducted is determined by reference to the ratio of interest (paid or payable) to another variable. In contrast to the thin capitalization rule which determines excessive debt on which interest payment deduction is available, this approach directly determines excessive interest on which interest deduction is allowed or disallowed. Deduction of interest expense is disallowed if the amount of interest exceeds a certain prescribed financial ratio. For instance, the deduction may be denied for interest expense (gross or net) that exceeds a fixed percentage (for example 30 percent) of a prescribed financial measurement, such as gross income less certain expenses, or the familiar earnings before interest, tax, depreciation, and amortization (EBITDA). Governments restrict interest deductibility by establishing limits on the ratio of interest expenses to earnings. Countries employ a ratio approach that focuses on the amount of interest paid or payable concerning the amount of income out which that interest is paid. This is sometimes referred to as an "earnings stripping" approach. The applicable ratio may be by reference, for example, to a ratio of the amount of interest to operating profit or a measure of cash flow.

Determining excessive interest utilizing a financial ratio or determining excessive debt (indirectly excessive interest) using the more traditional debt-to-equity ratio are not mutually exclusive approaches. For example, the US uses a combination of both approaches. Accordingly, interest expense is disallowed if the taxpayer breaches a debt-equity limitation, and also the interest expense exceeds fifty percent of adjusted taxable income.

\section{Ethiopia's Interest Deduction Rule}

As indicated above, debt financing is one source of the company's finance that may cause the problem of thin capitalizations when it is relatively greater than equity. Because of the deduction of interest payment on debt as an expense for tax purposes, overwhelmingly debt-financed capital can provide an opportunity for tax planning or tax avoidance and substantially reduce the tax due to the government. To counteract this problem of thin capitalization, Ethiopia has introduced thin capitalization rules or interest deduction rules to its income tax regimes [14]. Relative to the previous income tax regimes, the new income tax law has come up with relatively stronger thin capitalization rules. The following section examine the thin capitalization rules of Ethiopia under the new income tax laws. To this end, thin capitalization rules under the repealed income tax regime of Ethiopia is briefly discussed.

\subsection{The Repealed Interest Deduction Rules}

The deductions of expenses incurred to earn, secure, and maintaining the business income is allowed to the extent that the expenses can be, proven by the taxpayer and subject to the limitations specified by the law. Here, the term "expense" includes interest as far as the taxpayer able to prove that the debt on which interest is paid as an expense are incurred for earning, securing, and maintaining a business income. As a result, business income taxpayer has given the right to deduct interest on the debt from their gross income [15]. Such deduction reduces taxable income and tax liability. This triggered the need to limit to protect tax revenue without affecting the availability of finance to the company. Because of this, the deduction of interest is available only within the limit of the law and upon fulfillment of the requirements set by law.

First, the maximum interest rate within which deduction is allowed is the interest rate used between the National Bank of Ethiopia (NBE) and commercial banks plus two. For example, in case the interest rate used between the NBE and commercial banks is ten percent, the maximum interest rate for which deduction is available is twelve percent. Consequently, the amount of interest which arises from an interest rate more than the rate used between the NBE and the commercial banks increased by more than two percent is non-deductible interest. Based on the contrary reading, the amount of interest which arises from rate not over two percent of the rate used between the NBE and the commercial banks is deductible.

Second, the lenders must be institution recognized by the NBE or foreign banks which secure permission from the NBE to lend for enterprise in Ethiopia.

Third, before granting the loan, the lending institution must inform the tax authority about all loans granted to any person liable to pay income tax in Ethiopia. This requirement gives ample opportunity for the tax authority to examine inter alia the nature of the loan, the modality of repayment, the interest to be paid, the relationship of the parties, and other relevant matters relevant in finding tax avoidance activities.

Last but yet importantly, the borrower shall withhold ten percent from the gross interest payable to the lender and transfer the same to the Tax Authority within two months of the end of the fiscal year. The ten percent withholding obligation imposed on taxpayer reduce the loss of revenue of the government.

The previous income tax law has failed to adopt the internationally accepted approaches that limit interest deductibility through limiting excessive debt based on arm's length or ratio approach. However, the law had not tolerated the abuse resulting when the ratio of debt to equity is disproportionately higher to loan or advance granted by shareholders. Concerning debt from shareholders, the law has specified a maximum allowed interest deduction to the debtequity ratio of 4 to 1 . Following this, except for bank and insurance, interest paid to shareholders on loans and advances shall not be deductible to the extent that the loan or advances in respect of which the interest paid exceed on average during the tax periods four times the amount of the share capital. This indicates the adoption of a ratio approach in determining excessive debt for which deduction is allowed on interest. However, it is not a fully-fledged ratio approach (debt-equity ratio) as it applies only concerning debt secured from shareholders. The approach does not apply to debt secured from non-shareholders. In conclusion, the repealed 
tax laws has specified maximum interest on which deduction is available, withholding tax on interest, and debt-equity ratio concerning debt gained from a shareholder to mitigate the problem of thin capitalization.

\subsection{Existing Interest Deduction Rules}

The interest deduction rule is very essential to tackle base erosion and profit shifting involving interest payment. The thin capitalization rules usually operate through determining a maximum amount of debt on which deductible interest payments are available and/or interest which is deductible by reference to the ratio of interest paid or payable to another variable. More precisely, usually thin capitalization rule is designed in a way that determines maximum debt or interest on which deduction is allowed. The former is called thin capitalization or indirect interest deduction rule while the latter is called interest deduction rule or direct interest deduction rule or interest or earning stripping approach. The thin capitalization rule is considered as traditional approach relative to the interest deduction rule which is a modern one.

Interest above the excessive/maximum debt or interest is non-deductible. In determining a maximum amount of debt on which deduction of interest is available, different approaches are used. Among, arm's length and debt-to-equity ratio approaches were broadly used. The Ethiopia income tax proclamation has incorporated thin capitalization rules that limit the amount of interest that can be deducted in calculating the measure of a company's profit for tax purposes. In Ethiopia, thin capitalization rules operate by determining the maximum amount of debt. The interest deduction rule of Ethiopia has not incorporated earning or interest stripping rule which determines the maximum or excessive interest payment relative to earnings before interest, tax, depreciation, and amortization. In addition to operation by determining excessive debt, the thin capitalization rules of Ethiopia, operate by determining the maximum interest rate on which the deductible interest payments are available. Furthermore, interest deduction in Ethiopia by imposing withholding tax of interest paid to nonresident recipient of interest. In determining excessive debt, the income tax proclamation has incorporated arm's length and debt-equity ratio approach. Approaches of interest deduction rules in Ethiopia are discussed in the next section.

\subsubsection{Principle of Deductibility}

In principle, interest is deductible as expense or expenditure to determine the taxable income of the taxpayer for the tax purpose of the tax year. Such deduction is allowed for any interest incurred if the taxpayer has used to proceed, or benefit of the debt or other instrument that gives rise to the interest to derive business income [16]. The interest paid or payable to drive business income is deductible does not mean deduction is allowed without limit for all interest paid or payable by taxpayers within a tax year. Instead, the interest is deductible only subject to the following limits and the requirements of the laws.

First, the debt shall be deducted if it is incurred to drive business income. The debt on which interest is paid or payable by the taxpayer shall be deducted only if the debt is used to drive business income. Hence, even if interest is paid or payable by a taxpayer within a taxpayer, the interest may not be deductible unless the interest is proven to be used to derive business income. Here, the taxpayer has a burden to prove and convince, the debt on which interest paid or payable are used to drive business income. The issue in which circumstances does the debt is deemed to be used for driving business is not addressed both by the income proclamation and regulation thereof. In this regard, the repealed income tax law is comparatively clear. It has provided for the deductibility of proven expenses incurred to earn, secure, and maintaining a business income. Unlike the repealed income tax proclamation, the term "drive business income" under Art 23 of the current income tax proclamation seems to include only debt incurred to earn business income excluding proceed or benefit of debt used for purpose of securing and maintaining a business income. However, it is better to interpret as it also includes debt incurred to secure and maintain business income.

Second, the debt shall be deducted if the lender is authorized one. The lending institution may be a domestic or foreign lender. In the case of a foreign lender, the interest paid or payable to a lender is deductible only if the lender is authorized by the NBE to provide loans and the borrower or taxpayer has provided the tax authority with a copy of the letter of authorization issued by the NBE [17]. Thus, interest paid or payable to foreign lenders shall be deductible only if the lender is authorized to lend for the taxpayer and the taxpayer has provided a copy of such a letter of authorization to the tax authority. In other words, interest paid or payable on loan from the foreign lender which is not authorized by the NBE to provide loans is non-deductible. Previously, the foreign bank is duty-bound to inform the tax authority about all loans granted to any taxpayer of income tax in Ethiopia. Currently, this requirement is waived.

Third, the debt shall be deducted if the lending is within authorized limits. The interest on the debt is deductible only if the interest rate, amount of debt, and the debt-equity ratio is within the limit of the law. Concerning interest rate, except in case lender are financial institutions recognized by the NBE and authorized foreign banks, the maximum allowable interest rate for deduction is the rate used between the NBE and commercial banks increased by two percent. For this reason, an interest which arises from an interest rate which exceeds the maximum interest rate is non-deductible, for the tax purpose. Concerning the limit of maximum debt on which interest deduction is allowed the income tax law of Ethiopia have a specified debt to equity ratio of 2 to 1 for a tax year. Hence, interest paid on debt, whose debt-equity ratio is greater than 2 to 1 is not deductible. However, this limitation may not apply, if the amount of the average debt of the foreign-controlled company for the tax year does not exceed the arm's length debt amount. Meaning, even if the debt to equity ratio is greater 2 to 1 , the interest of such excess debt is deducible as far as the amount of the average debt of the 
company for the tax year does not exceed the amount of debt that a financial institution would be prepared to lend to the company in an arm's length transaction having regard to all the circumstances of the company.

\subsubsection{Interest Deduction Rules Approaches}

Tax law does not forbid an enterprise from having an excessive label of debt, however, that limit may be defined. In Ethiopia, the Federal Income Tax Pro. No. 979/2016, has thin capitalization rules that limit the deductible amount of interest for tax purposes. These thin capitalization rules operate by using two approaches determining the maximum amount of debt (debt-to-equity and arm's length test) and the interest rate (not excessive interest) on which the deductible interest are available. In addition to this, withholding tax on interest payments made to a non-resident is recognized as an interest deduction approach to minimize tax base erosion and profit shifting under the guise of the interest deduction.

Under the previous income tax regime, a limited interest rate, the debt-equity ratio with respect to loans from a shareholder, and withholding tax on interest were recognized as interest deduction approaches. As per the limited interest rate approach, the deduction of interest on the debt is allowed only within specified or limited interest rates. Because of this, the amount of interest that arises from the interest rate imposed on the debt above a given limit is non-deductible. The interest payment which arises from interest rate below a legal limit is deductible for tax purpose.

In determining the maximum allowable debt (excessive debt) on which interest is deductible, the new income tax law of Ethiopia introduced arm's length and debt-equity ratio approach. The interest deduction is available only within a limit of excessive debt that may be determined based on the debt-equity ratio and arm's length approach. The Federal Income Tax Pro. No. 979/2016 is a pioneer in introducing these approaches of thin capitalization rule into the Ethiopia income tax system. The introduction of these two approaches is a great step by the government in counteracting the tax avoidance or planning committed through thin capitalization.

Limiting Maximum or Excessive Debt

In Ethiopia, the maximum debt on which interest deduction are available can be determined based on the debtequity ratio and arm's length approach. Arm's length tests compare the level of debt in an entity with the position that would have existed had the entity been dealing entirely with third parties. In contrast, debt-to-equity ratio rules limit the level of debt in an entity with reference to a fixed debt-equity ratio.

Debt-to-Equity Ratio Approach (2:1)

The debt-equity ratio is the most frequently adopted approach to determine whether an enterprise has a reasonable amount of debt. Tax law disallows interest expense that arises from a debt-equity ratio higher than the prescribed ratio. The fact that the taxpayer's capital structure appears to have excessive debt supports the conclusion that the related interest expense is excessive and should not be allowed as a deduction for tax purposes. The debt to equity ratio approach is also known as ratio approach or debt to asset ratio. This approach uses the debt and equity ratio of the company in determining the maximum debt on which deduction of interest is allowed. The debt and equity of the company serve as a basis to determine the maximum amount of debt for which interest is deductible. For determining debt-equity ratio, the term "debt" includes any debt obligation of the foreign-controlled resident company on which interest is payable, while the term "equity" includes the greatest amount of the equity of the company at any time during the tax year and includes an obligation to make a repayment of money in respect of which no interest is payable. Here, the definition of the term equity is hardly a clear concept covering share, bond, and other assets on which no interest is payable.

In Ethiopia, the debt-to-equity ratio applies only to determine maximum debt on which interest is deductible for the foreign-controlled resident company. Thus, the debt-toequity ratio does not apply to determine maximum debt on which interest is deductible for a non-foreign-controlled resident company such as a domestic company. Except for foreign-controlled resident company operating as a financial institution, the law has specified a debt-equity ratio of 2 to 1 as a maximum allowable debt on which interest is deductible for tax purposes. For a foreign-controlled resident company, the debt to equity ratio of 2 to 1 is a "safe harbor rule". When the debt-to-equity ratio is below that figure, the tax authority will not question whether the debt is excessive. If the debt to equity is greater than a 2 to 1 ratio, the tax authority may or may not determine the debt is excessive, based on an examination of all relevant facts and circumstances using arm's length. If the average debt to average equity ratios of the foreign-controlled resident company exceed 2 to 1 deduction shall not be disallowed if the average debt of the company for the year does not exceed the arm's length debt amount. The debt to equity ratio exceeds 2 to 1 does not mean that deduction is automatically disallowed. Instead, exceeding the debt-equity ratio of fixed ration results in nondeductibility only if the amount of debt exceeds the arm's length debt amount. At this point, the arm's length debt amount refers to the amount of debt that a financial institution would be prepared to lend to the company in the arm's length transaction having regard to all the circumstances of the company. Determining the arm's length debt amount requires considering past and present operations of the company.

The higher debt-equity ratios is customarily permitted for financial institutions. This is because their assets are generally viewed as being more readily marketable. For instance, bank and microfinance institutions may hold as assets loans or receivables for which there is an easily identifiable market and market price, in the event the bank and microfinance institution needs to sell the assets to raise cash. Additionally, borrowing is a fundamental part of the business model of financial institutions. On the other hand, other non-financial company may have assets which are not easily marketable. The higher debt-equity ratios for financial institutions are readily observable in the marketplace. 
Consistent with international norms of setting different debtto-equity ratio for financial institutions, the thin capitalization rules of Ethiopia has set different debt to equity ratio for a financial institution and other foreign-controlled resident company. In this regard, Art 47 (1) of Pro. No. 979/2016, clearly provides that:

...If a foreign-controlled resident company, other than financial institutions, has an average debt to average equity ratio in excess of 2 to 1 for a tax year, a deduction shall be disallowed for an interest paid by the company during that year calculated according to the following formula $\mathrm{A}=\mathrm{XB} / \mathrm{C}$. $\mathrm{A}$ is the company's total amount of deductible interest for the year; B is the company's excess debt for the years, and C is the company's average debt for the year.

The first issue worth of discussion under this provision is the scope of applicability debt-equity ratio. Here, the scope of the applicability debt-equity ratio only to a foreigncontrolled resident company. This indicates, like Germany, thin capitalization rules of Ethiopia aim to focus specifically on the avoidance of abusive financing strategies in which the lender was a foreign shareholder or related party. In doing so, Ethiopian thin capitalization rules treated domestic and international firms investing in Ethiopia inequitably or differently giving preferential tax treatment for domestically owned Ethiopian Companies. This preferential treatment is legitimate. If the recipient of interest payment is a resident, such payment is taxable as part of the taxable income of the interest receiver. As a result, in case of debt is owed and interest is due, the risk of tax base erosion and profit shifting is low.

In Ethiopia, a foreign-controlled resident company is defined as a resident company in which more than fifty percent of the membership interests in the company are held by a non-resident either alone or together with a related person or persons. As a result, the debt-to-equity ratio may not apply to determine the maximum allowable debt on which interest is deductible for a foreign-controlled resident company in the membership interest of the non-resident person is less than or equal fifty percent. The debt-equity ratio also does not apply to the resident company fully controlled by the domestic investor.

Besides, the debt-equity ratio does not apply when the taxpayer businessperson other than a company such as a partnership and public enterprises. Foreign control or being a company is not a necessary condition for thin capitalization to occurs. Instead, thin capitalization may arise even in the case where a taxpayer or borrower is a person other than a foreign-controlled resident company as far as the resident person has raised its capital mainly based on debt financing using debt from abroad on which interest is paid or payable. Because of this, the exclusion of debt-equity ratio from being too applicable to a company and persons other than a foreigncontrolled company is a great weakness that needs revision.

The second issue worth of discussion is the inapplicability of a 2 to 1 ratio to financial institutions [18]. The financial institution relies on significantly more debt than nonfinancial institutions. Thus, the financial institution has higher debt-to-equity ratios compared with other companies. For this reason, some countries establish separate thin capitalization policies for them. Likewise, it seems Ethiopia has the interest to adopt a separate debt-to-equity ratio for financial institutions. However, both Pro. No. 979/2016 and regulation thereof have not determined the debt to equity ratio for financial institutions. This may raise the issues whether the interest on the debt of a financial institution is deductible without limit as far as the interest rate is within the rate specified under Art 23 of Pro. No. 979/2016. During the enactment of the new income tax law, the financial sectors of Ethiopia were closed to foreign ownership or control [19]. As a result, financial institutions of Ethiopia are fully controlled by Ethiopian investors who are most likely not a foreign resident [20]. Because of this, thin capitalization is not a big deal in the financial institutions of Ethiopia [21]. However, currently, Ethiopia has opened its financial services market for foreign nationals of Ethiopian origin. Following this, thin capitalization in financial institutions is a big issue for Ethiopia which needs a special debt-equity ratio because of its special nature. As indicated above, thin capitalization arises even in case the financial institutions are controlled by resident persons. Hence, the same analysis applies mutatis mutandis to the case of financial institutions.

The third issue worthy of discussion is the basis for determining the debt to equity ratio. In some jurisdictions, the debt to equity ratio of maximum allowable debt on which interest deduction is allowed is determined based on annual debt and equity, or asset at the end of tax years. However, in Ethiopia, the debt-to-equity ratio of the company shall be determined based on average debt and average equity. The average debt shall be calculated as the sum of the amount of debt of the company at the end of each calendar month in the tax year divided by twelve months. Likewise, the average equity of a foreign-controlled company is calculated as the sum of the amount of equity of the company at the end of each calendar month in the tax year divided by twelve months. Because of this, there is a need to search for effective thin capitalization rules to optimize it.

Different countries have adopted different debt-equity ratios to restrict the deductibility of interest on the debt for tax purposes. Comparatively, the debt-equity ratio specified by Ethiopia is tight. While the Ethiopia debt-to-equity ratio is lower than that imposed in other nations, this does not necessarily demonstrate the rules are effective at achieving its objective. Instead, different studies have proved that the debt to equity ratio rules is ineffective. It is possible to strip all earnings from Ethiopia as long as the debt-to-equity ratio is not exceeded. Besides, it is very simple for companies to circumvent the limit established by the debt-to-equity ratio by increasing the equity of the financed subsidiary in a manner sufficient to push down as much debt as necessary. Moreover, multinationals corporations can avoid debt-toequity constraints by injecting both equity and debt into a subsidiary-foreign controlled resident company. If the multinational corporations aim to reduce taxes, it can first 
calculate how much debt it wants to leverage on the subsidiary to strip earnings and then calculate how much equity must be invested to comply with debt-to-equity limitations. To solve this problem, Ethiopia should tighten its thin capitalization rules, to adequately control tax-motivated intercompany debt, and be cautious in regulating earning stripping activities.

In applying the debt-to-equity ratio, some issues need consideration. The debt-equity ratio is usually determined by examining a taxpayer's financial balance sheet. This makes it easy for administration but raises important questions. The equity of a company is often based on historical measures, such as the initial equity investment plus retained earnings. This may undervalue the asset side of the enterprise. The measurement of debt at current values but equity-based on historical data overvalue the debt side and affect the debtequity ratio accordingly. On the other side, measuring the equity of the company on a fair market value basis, make the valuation costly and complicated. In doing so, valuations potentially create controversy between the taxpayer and tax authorities.

In addition to the valuation of debt and equity of the company, the other issue worthy of consideration is fluctuating interest rates. Determining whether an interest deduction is allowable based on compliance with a maximum debt-equity ratio has one interesting and often overlooked shortcoming. The approach does not take into consideration the rate of interest paid on the debt. However, the interest rate can be keenly important in determining whether a particular amount of debt is reasonable or excessive.

In Ethiopia, the new income tax law has fixed the maximum interest rate on which deduction is allowed. Accordingly, the maximum interest rate specified as the rate used between the National Bank of Ethiopia and commercial banks increased by two percent. Exceptionally, this maximum interest rate limit does not apply in case the interest is payable to financial institutions recognized by the National Bank of Ethiopia or a foreign bank permitted to lend to persons in Ethiopia. This means an exceptional interest rate that exceeds the rate used between the NBE and commercial banks by two percent may be deductible, where the interest is payable to a financial institution recognized by the NBE or a foreign bank permitted to lends to persons in Ethiopia. In a low-interest-rate environment, a company may be able prudently to carry a higher level of debt than it could in a higher interest rate environment. For instance, the amount of income required for a company to comfortably support a loan may be very different based on whether the loan carries lower or higher interest rates.

Concerning financial institutions, the major challenge in determining appropriate debt-equity ratios is the fact that such institutions differ significantly in their business models. These differences arise concerning both sources of funding and the assets in which they invest. For example, banks that rely on deposits is different from banks that rely on shortterm borrowing in the commercial paper markets. A financial institution that invests in readily marketable securities or credit card receivables different from a financial institution that invests in capital goods leased to customers. These differences in funding and assets result in a debt-equity ratio that differs across financial institutions. For tax purposes, this creates the challenge of whether to apply a single permissible debt-equity ratio to all financial institutions as a bright-line test, or whether to seek to permit different ratios based on different business models. In this regard, the income tax law of Ethiopia neither adopted a single permissible debt-equity ratio to all financial institutions nor it permits different ratios based on different business models.

The issue that needs consideration under the debt to equity approach is the issue of determining the disallowed interest. The challenging issue here is how to determine the amount of interest that should be disallowed in the event a taxpayer exceeds a permissible debt-equity ratio. Presumably, the best approach is a form of proration, in which interest is disallowed based on the degree to which the enterprise exceeds the debt-equity limitation. But that test may be easier to describe than to apply.

Arm's Length Approach

The arm's length approach is the second approach adopted by the Ethiopian income tax proclamation. Under this approach, a foreign-controlled resident company is said to be thinly capitalized when it has an excessive debt with its arm's length borrowing capacity, leading to the possibility of excessive interest deductions. Further, the arm's length borrowing capacity of a foreign-controlled resident company in Ethiopia is the amount of debt which it could and would have taken from an independent lender or financial institution as a standalone entity rather than as part of a multinational corporation. Art 47 (2) of the Pro. No. 979/2016 state that "when the average debt to average equity ratio of a foreigncontrolled resident company exceeds 2 to 1 for a tax year, the debt-equity ratio of 2 to 1 which disallow deduction shall not apply if the amount of the average debt of the company for the year does not exceed the arm's length debt amount."

This indicates, even if the average debt to average equity ratio of a foreign-controlled resident company exceeds 2 to 1 for a tax year, deduction of interest may not be disallowed if the amount of the average debt of the company for the year does not exceed the arm's length debt amount. As a result of this, the interest on the debt which is not deductible under the debt to equity ratio of 2 to 1 may be deductible under arm's length approach. This happens, if the amount of the average debt of the company for the tax year does not exceed the arm's length debt amount. For this reason, interest on the debt which exceeds debt to equity ratio of 2 to 1 may not become automatically non-deductible.

In the case of debt to equity ratio approach, the excess debt for which deduction of interest is disallowed for a foreigncontrolled resident company is determined based on the average debt and equity of the company during the tax year. As result, the term "excess debt" is defined as the amount by which the company's average debt for the year exceeds the maximum average debt allowed for the year according to the 2 to 1 ratio. However, using the arm's length approach in 
determining maximum allowable debt for interest deduction is determined based on the arm's length debt amount which refers to the amount of debt that a financial institution would be prepared to lend to the company in an arm's length transaction having regard to all the circumstances of the company. The arm's length debt amount is determined by refers to the amount of debt that the financial institution would lend to the company in arm's length transaction based on all circumstances of the company. In doing so, the determination of arm's length amount is comparatively subjective as it is determined based on subjective concepts like arm's length transaction. Besides, the amount of debt is not dependent only on the circumstance of the company but also on the circumstance of the lender and country where the taxpayer is resident. However, the law uses all circumstances of the case to determine the amount of debt the financial would lend to the company at arm's length transactions. Even the term "all circumstance" is not clear, as it is not clear whether it covers the past, present, and/ or future situations of the company. Even though this issue is unsettled, it may include financial situations of the company such as profitability of the company, debt to equity ratio of the company, and others.

In Ethiopia, to determine whether a firm is thinly capitalized or not, first, the tax authority needs to ascertain how much the company or companies would have been able to borrow from an independent lender at arm's length transactions. This figure must be compared with the amounts borrowed from group companies or with the backing of group companies. The regulations then deny tax deductions for interest expenses that exceed a firm's arm's length debt capacity. In establishing the arm's length borrowing capacity of the foreign-controlled resident company, it is necessary to hypothesize foreign-controlled resident company and financial institution as separate entities borrowing and lending at arm's length transaction.

One key question with the arm's length approach is whether it gives taxpayers sufficient guidance to determine whether their debt or interest expense is excessive or not. Taxpayers may need more specific direction concerning how much debt violates the arm's-length standard. Arm's length standard is a hypothetical exercise. Because of this, it gives taxpayers little guidance and conflicts with the certainty canon of taxation. The absence of clear regulations also increases the likelihood of costly litigation. This can also make enforcing rules very inefficient. This may be why no other major countries have chosen this approach.

The arm's length approach under Pro. No. 979/2016 use financial institutions as a reference for "third party lender". Usually, this approach uses the amount of debt which "third party lender" is willing to lend to the company at arm's length transaction to determine the maximum amount of debt on which deduction of interest is available to determine the taxable income of the company. Because of this, determining who the third party lender is hardly clear. To solve this problem, the income tax proclamation has used the amount of debt that a financial institution would be prepared to lend to the company in an arm's length transaction having regard to all the circumstances of the company. Even though the third party lender is specified and clarified as a financial institution, the term "arm's length transaction" is not clear. Arm's length transaction is defined as the circumstance in which financial institutions and taxpayer companies act independently and at equal footing in the way they do not have any relationship with each other. The arm's length transaction helps to ensure that the amount of debt provided to the company based on a market basis. If the amount of debt the lender has provided to the taxpayer is more than the amount that the financial institution would provide to the taxpayer considering all circumstances of the company, such amount interest paid or payable on the amount of debt exceeding the maximum amount of debt that the financial institution is willing to lend at arm's length transaction is non-deductible.

The other issue is worthy of discussion is the applicability of arm's length approach in determining the maximum allowable debt of a non-resident company with a permanent establishment in Ethiopia. As discussed previously, the debtto-equity ratio approach does not apply to the resident company. Unlike, the ratio approach of determining maximum debt on which deduction of interest is available, according to Art 47 (3) of Pro. No. 979/2016, the arm's length approach shall be applicable in determining the maximum amount of debt on interest deduction is available to a non-resident company with a permanent establishment in Ethiopia. This happens because of the treatment non-resident company with a permanent establishment in Ethiopia as a foreign-controlled resident company. In contrast to an ordinary foreign-controlled resident company, the average debt to average equity ratio of the permanent establishment is calculated by reference to the debt obligations of the nonresident company attributable to the permanent establishment and the equity of the non-resident company attributable to the operations of the company conducted through the permanent establishment. Here, the excess debt is determined based on the debt obligation and equity of the company. The term debt obligation is different from debt. Debt refers those on which interest is paid or payable whereas debt obligation refers to an obligation to make a repayment of money to another person, including obligations arising under promissory notes, bills of exchange, and bonds, but not including accounts payable or an obligation to make a repayment of money in respect of which no interest is payable.

Finally, the arm's length approach under Ethiopia income tax law is not free from discriminating domestic and international firms as it does not treat firms equally. Unlike the debt to equity to ratio approach which is inapplicable to non-resident companies, the arm's length approach applies in determining the maximum allowable debt of a non-resident company with a permanent establishment in Ethiopia.

\section{Limiting of Maximum Interest [Rate]}

Limiting the maximum interest is also called earning or interest stripping approach is considered as a direct limitation of the interest deduction. Under this approach, deductible 
interest is limited relative to a stated percentage of the company's earnings before tax, or other financial measurements. Currently, different countries limit the net interest expenses of a company to a given percent of the taxable income before EBITDA expenses. Excess Interest means an interest amount that exceeds a given percent of the earnings before interest, taxes, depreciation, and amortization (EBITDA") [22]. While the interest limitation approach appears to resolve a number of the issues associated with interest deduction rules, it is not clear that the percent interest expense limitation is the correct figure for all businesses. The financial ratio or interest stripping approach has one primary virtue that it directly limits tax base erosion. A taxpayer cannot deduct interest over the limitation amount. By contrast, the debt-equity ratios has only an indirect limitation on base erosion. For instance, depending on interest rates, two companies with the same, permissible debt-equity ratios will have different levels of interest expense. Accordingly, one company's deductible interest expense may be much higher than the other company's level of interest expense. This is not the case under the interest stripping approach. Because of this fact, an approach of directly determining excessive interest on which deduction is allowed is widely appreciated as a modern and most effective measure that directly protect tax base erosion.

The interest deduction rule which denies interest deductions based on a prescribed financial ratio causes taxpayers to adjust their behaviour as interest rates fluctuate. In doing so, this approach creates positive incentives for a company to reduce its debt and accompanying interest expense when interest rates are rising. In contrast to the debtequity ratio, under this approach, determining the disallowed interest is generally easy. Because simply the disallowed interest is the amount of interest expense over the limitation.

Now, the question is whether this modern interest deduction rule is recognized under Ethiopian tax law or not. Unfortunately, Ethiopia law has not incorporated this approach. Rather, an Ethiopia income tax law has incorporated limiting the maximum allowable interest rate on which deduction of interest is allowed for tax purposes. Limiting the maximum deductible interest rate is different from limiting excessive interest on which deduction is allowed. As a matter of principle, any interest incurred for debt used to drive business income is deductible. Accordingly, in determining the taxable income of taxpayers, the taxpayers shall be allowed a deduction for any interest incurred by a taxpayer in a tax year to the extent that the taxpayer has used the proceed or benefits of debt or other instrument or agreement that giver rise to the interest to derive business income. This deductibility of interest on debt gives room for tax practitioners to avoid tax liability by increasing interest rates paid or payable on the debt. To counteract the problem of tax avoidance committed using high-interest rates, the Ethiopia income laws has provided a maximum allowable interest rate on which deduction is available for determining taxable income. Concerning this, both repealed and in force income tax proclamation have similar stands by setting a maximum allowable interest rate for deduction at the rate used between the NBE and commercial banks increased by two percent. Hence, no deduction shall be allowed for the interest paid or payable by a taxpayer in the excess of the rate used between the NBE and commercial banks increased by more than two percent. In doing so, the rule disallows a specified percentage of the interest expense irrespective of the nature of the payment. This rule operating by directly limiting interest on which is deduction is allowed without consideration of the amount of debt.

The maximum interest rate specified as "the rate used between the NBE and commercial banks increased by two percent" does not apply in case the interest is paid payable to a financial institution recognized by the NBE or a foreign bank permitted to lends to persons in Ethiopia. This means an exceptional interest rate that exceeds the rate used between the NBE and commercial banks by two percent may be deductible, where the interest is payable to a financial institution recognized by the NBE or a foreign bank permitted to lends to persons in Ethiopia. Now the issue is what the maximum deductible interest rate concerning interest paid or payable to financial institution recognized by the NBE or a foreign bank permitted to lends to persons in Ethiopia. Up to date, the law is silent; however, it needs to be addressed to ensure certainty. Most probably, the maximum deductible interest rate paid or payable to financial institutions recognized by the NBE or a foreign bank permitted to lend to persons in Ethiopia will be greater one that can be paid or payable to other lenders or recipient. The failure of tax rules of Ethiopia to fix the maximum interest rate that is applicable concerning interest paid or payable to financial institutions recognized by the NBE or a foreign bank permitted to lend to persons in Ethiopia is one gap in the interest deduction rules within the corporate tax system of Ethiopia.

The purpose of an exceptional maximum interest rate financial institution recognized by the NBE or a foreign bank permitted to lend to persons in Ethiopia is not to discriminate borrower, but to encourage legitimate lending and borrowing. The external loan which led to the rise of interest payment is highly related to foreign exchange regulation. To regulate foreign exchange, the NBE has enacted Directive No. FXD/47/2017. As per this external loan directive, the borrower shall borrower only if the loan is guaranteed by the Federal Government and registered by the NBE or gets approval from the NBE before entering into the loan agreement. For registration and approval of the external loan, the NBE shall consider the draft loan agreement with detailed terms showing interest rates and applicable charges, loan disbursement schedules, repayment schedule, borrowers' lender relationship, the purpose of the loan, and other particulars as may be deemed necessary by the NBE. The repayment of the external loan is also subject to strict regulation of the NBE [23]. Because of this, the possibility in which the lender lends at a rate that causes a room for tax avoidance or tax planning is less. 
The other issue worthy of discussion is the nondeductibility of interest paid or payable to a related person who is a resident of Ethiopia. As per Art 23 (2(b)) of Pro. No. $979 / 2016$, no deduction is allowed on interest paid or payable by a taxpayer to a related person who is a resident of Ethiopia. However, exceptionally the interest is deductible when the interest is included in the schedule ' $\mathrm{D}$ ' of the related persons. This provision seems to be designed to avoid tax avoidance activity between related persons. However, the law is not clear about interest paid or payable by a taxpayer to a related person who is not a resident of Ethiopia concerning their income whose source is Ethiopia.

Withholding Tax on Interest

Developing countries traditionally favor withholding taxes on payments of interest to non-resident lenders. The same is true in Ethiopia. The withholding tax is perceived as a tax cost to the non-resident lender, with the benefit of raising tax revenue that partially offsets the tax cost of the local interest deduction. In Ethiopia, withholding tax on interest is one way of protecting tax revenue or reducing interest paid or payable to the lender. In other words, it is one measure of limiting interest deduction to protect the tax base and revenue thereof. However, the issue of whether or not it is considered as thin capitalization or interest deduction rules is debatable. Despite this fact, as the report of Organization European Cooperation for Development shows withholding tax on interest payments, which are used to allocate taxing rights to a source jurisdiction, is one of the existing approaches applied by European countries to tackle base erosion and profit shifting involving interest. Similarly, in Ethiopia withholding tax on interest payment is recognized as interest deduction rules. However, withholding tax on interest payments differs from other interest deduction rules. Other thin capitalization rule limits debt financing to protect tax revenue by limiting the deductibility of interest paid or payable on the debt and discourages debt financing. Withholding tax on interest has no effect of discouraging the borrower or limiting debt finance and financing. Because withholding tax is not imposed on the taxpayer but it is imposed on non-resident lender because of its sources of income in Ethiopia. Besides, the withholding tax imposed on interest does not affect the taxable income of the payer company. The withholding tax imposed on non-resident did not increase costs to the lender. Rather, the cost of the withholding tax goes to the country in which the lender was a taxpayer as the lender can able to claim the foreign tax credit. Withholding tax on interest has a significant effect on protecting tax revenue or reducing interest paid or payable to the lender without affecting the tax paid or payable by the borrower company.

Under the existing income tax regime, a non-resident who has derived an Ethiopian source interest shall be liable for non-resident tax at a rate of ten percent of the gross amount of interest. This does not apply to interest that is attributable to a business carried on by non-resident through a permanent establishment in Ethiopia. A non-resident who drives Ethiopian source interest that is attributable to a permanent establishment of the non-resident in Ethiopia shall be liable for withholding income tax of different rates based on the kind of lenders and source of interest. Accordingly, a nonresident who drives Ethiopian source interest that is attributable to a resident of Ethiopia or a permanent establishment of the non-resident in Ethiopia shall be liable for income tax at the rate of five percent of the gross amount of interest in case of a saving deposit with a financial institution. In any other case (in case the lender is not a financial institution and interest paid not with respect saving deposit with a financial institution), a non-resident who drives Ethiopian source interest that is attributable to a resident of Ethiopia or a permanent establishment of the nonresident in Ethiopia shall be liable for income tax at the rate of ten percent of the gross amount of interest.

The issue worthy of consideration concerning withholding tax is how to determine the appropriate withholding tax rate. In this regard, the first perspective is that if the local corporate income tax rate (30 percent) is higher than the withholding tax rate (10 percent), a tax rate arbitrage arises that reduces tax revenues, so to avoid the arbitrage the withholding tax must set at the same rate as the local income tax rate. The second perspective is that the withholding tax rate arguably should be set at a level that mirrors the tax revenues that would be raised if the lender were a domestic company [24]. . In that case, a fairly low withholding tax rate may be appropriate as a proxy for a tax on net income. Ethiopia adopted the second perspective.

The other issue of concern is whether the withholding tax rate should be different or similar to others if the lender is a financial institution. The financial institutions often have high leverage ratios or debt-equity ratios, which increase the interest expense from the loan to other companies. In such a case, even ten percent of withholding tax would appear too high compared with the tax revenue derived from lending financial institution on its domestic loan. Here, one way addressing the difficulty of determining an appropriate withholding tax rate on cross-border payments of interest is to adopt differential rates, and this is often the approach followed in tax treaties. When the lender of a loan is a financial institution, a treaty may impose lower withholding tax rates than when the loan is extended by a non-financial institution that may not have significant interest expense of its own. Similarly, the income tax law of Ethiopia has adopted a different tax rate on interest payments when the loan is extended by the financial institution and non-financial institution. Accordingly, in case the recipient of the interest is a non-resident financial institution, the interest payment is subject to a five percent tax rate. However, this rate is not applicable concerning interest which arises any debt, but the only interest which arises from saving a deposit.

At the moment it pays interest to a non-resident, resident of Ethiopia or a permanent establishment in Ethiopia of nonresident paying interest shall have the duty to withhold tax from the gross amount of the interest at a rate ten percent. Once it has withheld tax on interest, the taxpayer or borrower shall have the duty to pay to the authority within 30 days after the end of months in which the withholding income was 
paid Unlike the previous income tax regimes, currently deduction of interest may not be disallowed for tax purpose in case of taxpayer or borrower fails to withhold tax on interest. Instead, the taxpayer or borrower is made personally liable to pay the amount of tax to the authority, to pay the amount of tax to the authority if it fails to withhold tax or fails to pay withheld tax to the tax authority as required. Once the taxpayer or borrower who is acting as a withholding agent for tax on interest paid or payable to the non-resident person has personally paid the amount of tax due to tax authority, the borrower is entitled to recover the tax paid from the recipients of the payment.

\subsubsection{Concern of Gross or Net Interest and Debt}

Determining whether a taxpayer has excessive debt or interest, triggers the issue of whether the debt-equity ratio is based on gross debt (treating cash as an asset) or net debt (such that gross debt is reduced by cash). Likewise, should the calculation of whether a company incurs interest expense in excess of a prescribed limitation be made based on gross interest expense or net interest (gross interest expense minus interest income) is a fundamental issue. There is, of course, no single right answer. And both approaches are readily administrable since the data required to apply either approach lies in the financial statements and tax return information. [25] However, there are differences between the two approaches. For instance, a taxpayer may have high debt, but also high cash balances. Should interest payments on the debt be viewed as excessive and base eroding, or does the fact that the company has available cash (which may be earning interest income) dampen any tax concern about base erosion?.

The key point for tax administrators and taxpayers to recognize is that the question of whether to adopt a test that uses gross debt and gross interest or net debt and net interest expense will have a major impact on what ratios or financial limitations should be adopted.

In Ethiopia, the debt-equity ratio shall be calculated based on gross debt. Likewise, the withholding tax is imposed on gross interest.

\subsubsection{Tax Treatment of Disallowed Interest}

Assuming that a taxpayer has "excess" interest in a taxable year, the question arises whether the excess amount should be permanently disallowed as an interest deduction, or whether the interest should be carried forward and allowed as a deduction in a future year when the taxpayer fully satisfies the limitations on interest expense. Because of business cycles, some measure of carry-forward may be appropriate. The interest expense would be allowable in the future year only to the extent the enterprise incurs interest expense in the future year that is less than the amount otherwise allowable in that future year. Such a carry-forward rule would, of course, create administrative challenges for both government and taxpayers. In the event there is not a carry-forward rule, then a question arises as to how to characterize the disallowed interest payment. Should the payment be treated as a dividend in the current year? If so, would the applicable withholding tax be the rate of withholding on dividends, rather than the rate on interest? What is the tax impact of the recharacterization in the recipient's country? These issues can all be answered, but they require that explicit rules be issued to minimize tax disputes. In Ethiopia, per art 26 of the income tax proclamation is allowed if the total deduction of the tax years exceeds the total business income of the taxpayer for the year the amount of the excess shall be a taxpayer's loss for the year. In such a case, the taxpayer can forward the loss to the next tax years. However, the taxpayer shall not forward for more than five years.

\subsubsection{Consideration in Treatment of Interest}

A debt of company may be incurred to form or expand the business, to purchase a property that result in payment of interest, and the form of credit as a source of funding for the ongoing operations of a business. In this regard, there is a view that all interest expense should be considered as a single item of expense for determining in determining taxable income. On the other hand, there is an approach that calls differential treatment of interests. For instance, tax rules may treat debt incurred on initial capital differently from debt incurred for the ongoing operations of a business, either for the purchase of goods or services or as a credit. In order to encourage equity financing during company formation, the tax law may disallow deductions of interest which arise form debt-equity ratio that exceeds a stated level. In contrast, interest attributable to specific purchases of goods or services would be viewed as ordinary business expenses and fully deductible.

Determining whether to treat all interest alike as a single expense item or whether to treat some interest differently from other interest in terms of deductibility, require consideration of several factors such issues of administration, the effect on base erosion, and other policy reason. From an administration angle, treating all interest expense as a single item is generally easier for both taxpayers and tax authorities. Otherwise, taxpayers and tax officials must analyze the sources of debt and separate interest payments into different categories for purposes of tax deductibility. Furthermore, the different tax treatment of interest expenses depending on the source of the debt encourages taxpayers to favor certain kinds of debt and disfavor other kinds of debt. In doing so, different treatment of interest affects the behaviors of taxpayers. The other factor which needs consideration is the effect of debt on tax base erosion. Some kinds of debt may be more susceptible to abuse than others. For instance, if a company is formed with a combination of equity and debt, interest paid on this initial debt which is paid to a related person may be viewed as being created artificially and seen as more likely to be an improper base erosion payment than the interest paid to an unrelated party in connection with the purchase of a property. The other factor that needs consideration is the policy reason that is the effect of deduction on investment interest. Allowing full deductibility for interest on purchases of property, and capital goods encourage business operation and expansion. The same 
argument could be made for allowing full deductibility of interest paid on initial debt investment into the capital of a company, but the argument is generally more immediate and persuasive in the case of debt related to ongoing operations. [26].

In Ethiopia, the first approach is adopted. Accordingly, all interest expenses are treated as a single expense and subject to the same treatment concerning deductibility for tax purposes. If the need to treat different interest expenses differently, the government of Ethiopia should weigh these factors. In the researcher view, the government should give special treatment to interest incurred for research and development to encourage investment in research and development.

\subsubsection{Interest Paid to Related Parties}

The other fundamental issue regarding the deductibility of interest payments arises in connection with the payment of interest to related parties. Payment of interest to related-party is a concern only when the related party receiving the interest is outside the country of the party that is paying the interest. In other words, in the case the two related parties are in the same country and subject to local country tax, the interest payment is not a concern. However, when the related party receiving interest is located outside the country of the interest payer, the debt and interest payments thereof is viewed as a risk for tax base erosion[27]. The interest paid to related parties raise several concerns. First, the related parties may fashion a loan in a way that has the most favorable tax result. This happens when the interest is deductible, subject to low or no tax. Second, the concern arises because related-party loans are not subject to market discipline, in the way that debt from an unrelated party would be. The amount of the loan may be in excess of the amount that a third party would be willing to lend, or the loan may be for an extended period or subject to low interest than a third party would demand. Finally, there can be transfer pricing concerns with respect to the rate of interest paid and other terms of the loan. These concerns do not suggest a single answer regarding whether interest paid on related-party debt should be subject to different tax terms than the interest paid on debt to parties that are not related. From the perspective of the country in which the interest expense arises, if the recipient of the interest payment is related to the payer, there is a potential for transfer pricing abuse. In such a case, disallowing some or all of the interest paid to a related party is a means of addressing potential abuse. Besides, even if the amount of interest paid is appropriate, there is a concern that the interest may not be properly taxed in the hands of the recipient.

On the other hand, treating related-party interest less favorably creates costs [28]. In particular, imposing additional costs on the use of debt may affect investment decisions. Besides, enforcing special rules on related-party lending creates administrative costs. In Ethiopia, the tax law has treated related and non-related parties concerning debt to equity ratio.

\subsubsection{Tax Treaties Analysis}

As of today, Ethiopia has signed several treaties that affect the taxation of interest. Such a treaty, limit the taxing authority of Ethiopia to foster trade and economic growth. As a result, in fashioning its tax rules that affect the taxation of interest or limit the availability of deductions for interest expense, Ethiopia does not has unfettered discretion. Hence, tax law provisions of Ethiopia that deal with limiting interest deduction concerning interest paid to or incurred by a nonresident shall be seen in the light of tax treaties signed by Ethiopia. In this regard, Art 48 of the income tax proclamation has recognized the supremacy of tax treaties over domestic tax laws.

\section{Concluding Remarks}

The use of interest is one of the profit-shifting techniques available in international tax planning. The fluidity and fungibility of money make it a relatively simple exercise to adjust the mix of debt and equity in a controlled company. When the level of debt capital is much greater than the equity capital of the company thin capitalization occurs. Thin capitalization reduces government income from tax by increasing deductible interest paid or payable on the debt. Nowadays, thin capitalization is one of the major challenges to the corporate tax of Ethiopia. Generally, to combat the problems of thin capitalization, countries have adopted different approaches to interest deduction rules to reduce deductible interest paid or payable on the debt. Predominantly, interest deduction rules operate either by determining the maximum amount of debt or interest on which interest deduction are available. To address the problem caused by interest deductibility on tax base erosion and profit shifting, Ethiopia has implemented tax rules restricting the deductibility of interest payments. As the finding has revealed, the newly enacted federal income law has taken a big step in tightening the interest deduction rules through the adoption of debt-to-equity ratio and arm's length approach to determine the maximum debt on which interest deductible. In doing so, the income tax rules of Ethiopia incorporated the indirect interest deduction rule which indirectly limits the amount interest on which is deduction is allowable. In addition to this, the withholding tax imposed on interest paid to non-resident and limit on maximum deductible interest rates are adopted as an interest deduction approach to supplement arm's length and debt-to-equity ratio to protect tax base erosion. Based on the debt-to-equity approach, the interest is deduction is available for the foreign-controlled resident company to the extent that the debt to equity ratio of the company does not exceed 2 to 1 . Exceptionally, an interest which arises from debt to equity ratio greater than 2 to 1 is deductible based on the arm's length approach, if the amount of debt in question is not greater than arm's length debt amount or amount of debt that the financial institution would be prepared to lend to the company in an arm's length transaction having regard to all the circumstances of the company. 
Besides, the new tax law has limited the maximum interest rate on which deduction is available. Because of that, the maximum interest rate specified on which interest deduction is available is the rate used between the NBE and commercial banks increased by two percent. This limit does not apply where the lender financial institutions recognized by NBE or foreign lender permitted by the NBE. Concerning interest is payable to financial institutions recognized by the NBE or a foreign bank permitted to lends to persons in Ethiopia, the maximum interest rate on the deduction is available is not defined.

Despite these positive developments, the Ethiopian tax law has failed to recognize direct interest deduction rules which directly limit the maximum interest on which deduction is allowed. Nowadays, interest stripping rule is widely appreciated as the modern and most effective approach directly restrict interest deduction. So, the failure to introduce a direct interest deduction rule is one of the major defect interest deduction rules in Ethiopia. Besides, the income tax law has failed to expressly set the special debt-equity ratio that applies to financial institutions. Furthermore, the tax law has failed to set a maximum deductible rate that applies to financial institutions licensed to lend in Ethiopia.

To fill these gaps and ensure efficient protection of the tax base against erosion by deduction of interest payment, the researcher called for a direct interest deduction rule. Besides, the researcher called for the introduction of a debt-equity ratio that applies to the financial institution and the maximum deductible interest rate concerning the interest payment to legitimate financial institutions.

\section{References}

[1] OECD Secretariat, Thin Capitalization Legislation, A Background Paper for Country Tax Administrations, (2012).

[2] Sotirios Apostolou, Thin Capitalization in the OECD, the EU and Sweden: Policy Responses, Evaluation and Alternatives, (Lund University, Master's Thesis), (2018).

[3] Stuart Webber, Thin Capitalization and Interest Deduction Regulations, COPENHAGEN RESEARCH GROUP ON INTERNATIONAL TAXATION CORIT DISCUSSION PAPER NO. 8., 5 (2010).

[4] Mathew Olusanya, Transfer Pricing, and Thin Capitalization, (2013).

[5] Stuart Webber, Thin Capitalization and Interest Deduction Rules: A Worldwide Survey, TAX NOTES INTERNATIONAL, Vol. 60 (2010).

[6] Alexandra Maßbaum and Caren Sureth, Thin Capitalization Rules and Entrepreneurial Capital Structure Decisions, BUR BUSINESS RESEARCH OFFICIAL OPEN ACCESS J. of VHB, Vol. 2, Is. 2, 147-169, 147 \&165(2009).

[7] Thiess Buettner et. al., Corporate Taxation, and ThinCapitalization Rules, (2006).

[8] Michael Overesch and Georg Wamser, Corporate Tax Planning and Thin-Capitalization Rules: Evidence from a Quasi-Experiment, (2007).
[9] Jennifer Blouin et. al., Thin Capitalization Rules, and Multinational Firm Capital Structure, IMF WORKING PAPER WP/14/12, (2014).

[10] Thiess Buettner and Michael Overesch, The Impact of ThinCapitalization Rules on Multinationals' Financing and Investment Decisions, CESIFO WORKING PAPER NO. 1817, (2006).

[11] Peter A. Barnes, Limiting interest deductions, in UNITED NATIONS HANDBOOK ON SELECTED ISSUES IN PROTECTING THE TAX BASE OF DEVELOPING COUNTRIES 155, 167 (, Alexander Trepelkov, Harry Tonino and Dominika Halka eds.., 2015).

[12] OECD, Limiting Base Erosion Involving Interest Deductions and Other Financial Payments, Action 4 -2016 Update: Inclusive Framework on Base Erosion and Profit Shifting, OECD/G20 Base Erosion and Profit Shifting Project, OECD Publishing, Paris. http://dx.doi.org/10.1787/9789264268333en, 23(2017).

[13] OECD, Action Plan on Base Erosion and Profit Shifting, OECD PUBLISHING, (2013), see http://dx.doi.org/10.1787/9789264202719-en, Available at 19/1/20191:05AM.

[14] Federal Income Tax Proclamation No. 286/2002.

[15] Council of Ministers Income Tax Regulations No. 78/2002.

[16] Federal Income Tax Proclamation 979/2016.

[17] Council of Ministers Federal Income Tax Regulation No. $410 / 2017$.

[18] Banking Business Proclamation No. 592/2008.

[19] Micro-Financing Business Proclamation No. 626/2009.

[20] Insurance Business Proclamation No. 746/2012.

[21] National Bank of Ethiopia Establishment (as Amended) Proclamation No. 591/2008.

[22] Jinesh R Bhagdev \& Srilakshmi Pai, Thin Capitalization Rules - Limitation on Interest deduction in certain Cases Section 94B, (2017), PP-3.

[23] National Bank of Ethiopia External Loan Directive No. FXD/47/2017.

[24] Alfons J. Weichenrieder and Helen Windischbauer, ThinCapitalization Rules and Company Responses Experience from German Legislation, CESIFO WORKING PAPER NO. 2456, (2008).

[25] Enken Cohrs, Interest Deduction LimitationRules in Sweden and Germany: A Comparison Regarding EU LawCompatibility and Appropriateness, (Master Thesis, Lund University), (2013).

[26] Ernst \& Young LLP, Thin Capitalization Regimes in Selected Countries, Report Prepared for the Advisory Panel on Canada's System of International Taxation, (2008).

[27] Yosef Alemu Gebreegziabher, Ethiopian Law on Transfer Pricing: A Critical Examination.

[28] Michael Overesch, The Impact of Thin-Capitalization Rules on Multinationals' Financing and Investment Decisions, CESIFO WORKING PAPER NO. 1817, (2006). 